Author: L Steynberg and D Millard

DISTINGUISHING BETWEEN PRIVATE LAW AND SOCIAL-SECURITY LAW IN

DEDUCTING SOCIAL GRANTS FROM CLAIMS FOR LOSS OF SUPPORT

ISSN 1727-3781

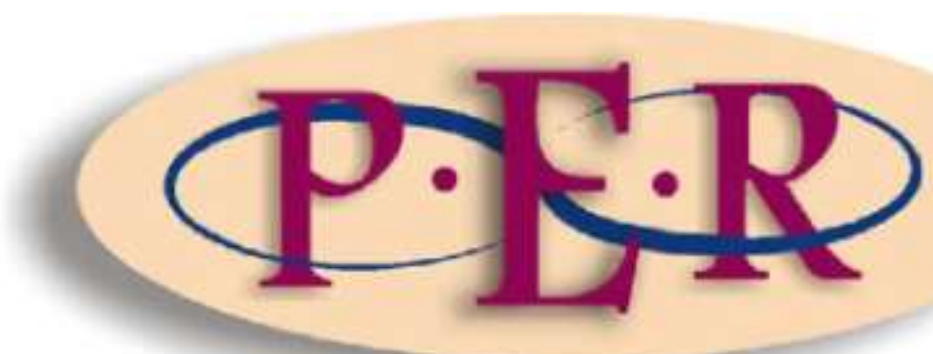

2011 VOLUME 14 No 4

http://dx.doi.org/10.4314/pelj.v14i4.9 


\section{DISTINGUISHING BETWEEN PRIVATE LAW AND SOCIAL-SECURITY LAW IN DEDUCTING SOCIAL GRANTS FROM CLAIMS FOR LOSS OF SUPPORT ${ }^{\#}$}

\section{Steynberg* \\ D Millard ${ }^{\star *}$}

\section{Introduction}

A damage-causing event often not only causes loss but sometimes also leads to a plaintiff receiving some benefit. For instance, where a breadwinner is wrongfully and culpably killed by a wrongdoer and the dependants of the deceased claim damages from the wrongdoer for loss of support, the damage-causing event is the killing of the breadwinner. The loss caused is the loss of support, and the benefits to be received could be the value of a life insurance policy or, more relevant to the topic under discussion, the payment of a social grant to the now indigent family.

Two recent conflicting decisions in Makhuvela $v$ Road Accident Fund ${ }^{1}$ and Road Accident Fund $v$ Timis, ${ }^{2}$ on the deductibility of social grants in claims for loss of support resulted in uncertainty about what the correct position in our law is in these cases. The ultimate question to be answered in the light of these two conflicting decisions is whether a general rule can be formulated on the deductibility of social grants from claims for loss of support or whether it is satisfactory to make decisions on a case to case basis, depending on the facts of each case.

In an attempt to answer this question we will illustrate in this article the difficulty of applying well-established private-law principles to social-security cases. Although

\# This article is based on two papers read by the authors at a seminar on double dipping hosted by the University of Johannesburg on 30 August 2010.

Loma Steynberg. Blur LLB LLM (PUCHO) LLD (Unisa). Professor, Department of Private Law, Unisa (Steynl@unisa.ac.za).

** Daleen Millard. BIur LLB LLM (UP) LLD (UJ). Associate professor of Private law, Faculty of Law, University of Johannesburg (dmillard@uj.ac.za).

Makhuvela v Road Accident Fund 20101 SA 29 (SGHC). See also Van Niekerk 2009 JILB 146.

Road Accident Fund v Timis 29/09 2010 ZASCA 30 (26 March 2010). See also Millard "Law of Third Party Compensation". 
private law and social-security law may have different objectives, these two areas interact and it must also be remembered that they both fall squarely under the Constitution. ${ }^{3}$ Importantly, this article will show that the well-established private-law principles cannot be automatically applied to cases involving social-security benefits. Furthermore, we will debate the wisdom of promulgating more regulations and will conclude the article with identifying possible guidelines to be applied in formulating rules where a case involves both private-law compensation and the payment of social grants.

\section{Theoretical background}

\subsection{Assessing claims for loss of support}

Assessing a claim for loss of support is a complicated process in which different mathematical calculations must be made and therefore an expert, usually an actuary, is appointed to assist in making these calculations. Claims for future loss are characterised by uncertainty and in quantifying such claims many assumptions are made. ${ }^{4}$ These assumptions will in many respects form the basis of the actuary's calculations and it is therefore very important that a factual basis be found for most of the assumptions, as their absence could jeopardise the credibility of the calculations. ${ }^{5}$ For instance, in finding a factual basis courts make use of evidence relating to events from the damage-causing event to the date of trial or settlement to establish a credible basis for assumptions about future losses. ${ }^{6}$ One of these assumptions could relate to a real or potential benefit that the dependant will or could receive in the future. So where a widow had been the recipient of a child-support

3 Constitution of the Republic of South Africa, 1996. Social security law and private law are part of the same system. See Pharmaceutical Manufacturers Association of SA: in re ex parte President of the Republic of South Africa 20003 BCLR 241 (CC) para 44: "There is only one system of law. It is shaped by the Constitution, which is the supreme law, and all law, including the common law, derives its force from the Constitution and is subject to constitutional control". See also the minority judgment of Froneman J in Mankayi v Anglo Gold Ashanti Ltd 40/10 2011 ZACC 3 (3 March 2011) para 124: "There is an impossible tension between asserting the fundamental supremacy of the Constitution as the plenary source of all law, and nevertheless attempting to conceive of an area of the law that operates independently of the Constitution".

Visser and Potgieter Law of Damages 125.

Visser and Potgieter Law of Damages 125

Visser and Potgieter Law of Damages 131. 
grant from the date of loss up to the date of trial or settlement, there is a chance that she will continue to receive this grant in future. But, even before this real or potential benefit is quantified, a decision must first be made whether this real or potential benefit should be disregarded in assessing the claim for damages or whether it should be taken into account.

If a benefit is disregarded in calculating damages, it is usually said that the collateralsource rule applies in that the receipt of such benefit is a collateral matter which does not concern a defendant and it is therefore res inter alios acta. ${ }^{7}$ If a benefit is taken into account, the benefit may be described as a compensating advantage, in other words, an advantage which in itself already acts as a form of compensation.

In social-security law "double dipping" is the term used to describe those instances where a beneficiary is entitled to claim benefits from more than one social security fund. Double dipping and the collateral-source rule do not actually relate to the assessment of loss, but rather to the quantification of the damages. ${ }^{8}$

\subsection{Deducting benefits in quantifying the damages}

Obviously, the real question is when the collateral-source rule will apply. Legal practice deals with the problem casuistically, while jurisprudence has not really been able to develop a generally acceptable theory. ${ }^{9}$ According to Van der Walt and Midgley ${ }^{10}$ the collateral-source rule serves as an ex post facto rationalisation of a judge's conclusion that a benefit derived from a particular source is legally irrelevant to the claim before the court. They continue to state that the exact basis for the approach is unclear and controversial, and this is compounded by the anomalous results reached in practice. ${ }^{11}$

Visser and Potgieter Law of Damages 204.

Visser and Potgieter Law of Damages 207. See also Van der Walt and Midgley Delict 200.

Visser and Potgieter Law of Damages 204. See para 2.3 below.

Van der Walt and Midgley Delict 199.

See also Boberg Law of Delict 479: "The existence of the collateral source rule can therefore not be doubted; to what benefits it applies is determined casuistically: where the rule itself is without logical foundation, it cannot be expected of logic to circumscribe its ambit". See para 2.3 below. 
In spite of this it can be said that it is well established in our law that certain benefits which a plaintiff may receive are always to be disregarded as being completely collateral. The two generally accepted examples are benefits received by the plaintiff under ordinary contracts of insurance for which the plaintiff has paid the premiums ${ }^{12}$ and moneys and other benefits received by a plaintiff as a solatium or from the generosity of third parties motivated by sympathy. ${ }^{13}$ One could also add instances where legislation expressly states that the benefit received must be disregarded. ${ }^{14}$ In these cases no uncertainty arises and it is clear that the collateral-source rule applies.

On the other hand, there are instances where it is immediately evident that the collateral-source rule will not apply and that the benefit will be deducted. For instance, legislation may stipulate that the benefit received must be deducted from any other claim based upon the same damage-causing event. ${ }^{15}$

Of particular concern then are those instances where it is unclear whether a benefit received should be deducted from a claim for damages or whether the collateralsource rule will apply. Here the applicable legislation is silent or it may be that conflicting statutory provisions apply to the same situation. ${ }^{16}$ Where such matters are adjudicated by the courts and conflicting decisions emerge, it worsens the situation. This confusion is particularly evident from the two recent cases under discussion in this article. ${ }^{17}$

12 Visser and Potgieter Law of Damages 211; Neethling and Potgieter Delict 228.

13 Visser and Potgieter Law of Damages 209-210; Neethling and Potgieter Delict 229-230.

14 Eg s 1 Assessment of Damages Act 9 of 1969: "When in any action, the cause of which arose after the commencement of this Act, damages are assessed for loss of support as a result of a person's death, no insurance money, pension or benefit which has been or will or may be paid as a result of the death, shall be taken into account".

15 Eg disability pension in terms of the Social Assistance Act 13 of 2004 (hereafter the SAA). See also Neethling and Potgieter Delict 230.

16 Plamondon Actuarial Practice 72: "Although the social security laws of some countries are quite explicit, many contain only minimal information. Laws are normally complemented by regulations that are regularly updated. When the laws and regulations are too vague or silent, the actuary must analyse the actual operation of the scheme, that is, the interpretation by the personnel responsible for the collection and recording of contributions and for the processing of claims. Some schemes may have been put in place with a minimal set of provisions, with the management benefiting from a highly flexible interpretation of the law. Over time, this may lead to an irregular treatment of cases".

17 See para 3 below. 


\subsection{Applying private-law principles to determine the deductibility of benefits}

In a claim for damages various principles underlie the application of positive law in assessing the loss suffered and the quantification of the damages to be awarded. In quantifying a claim for damages the object of the award of damages must be realised, namely the fullest possible compensation of the loss suffered. ${ }^{18}$ The aim is to place the plaintiff in the financial position he would have been in, had the damagecausing event not taken place. Therefore, the plaintiff should not be in a better position but should also not be worse off.

In deciding what amount would fully compensate the victim, the court must weigh up two apparent conflicting principles. ${ }^{19}$ The one is that a plaintiff should not receive double compensation ${ }^{20}$ and the other is that the wrongdoer or his insurer should not be relieved of liability on account of some fortuitous event such as the generosity of a third party. ${ }^{21}$ It has been said that in weighing up these two principles the courts should take into account considerations of fairness, public policy, reasonableness and justice. ${ }^{22}$ These considerations or concepts of so-called fairness and justice are not always easy to apply because they are not clearly defined.

Academic writers have attempted to clarify these concepts and we have also seen various case decisions on the application of these considerations. According to Visser and Potgieter, ${ }^{23}$ the collateral-source rule deals with how the beneficial results of a damage-causing event should be taken into account in view of the interests of the plaintiff, the defendant, the source of the benefit, the community and any other interested party, while applying certain basic principles. They argue that although notions of equity, reasonableness et cetera have an important function in the field of

\footnotetext{
18 Visser and Potgieter Law of Damages 4.

19 McKerron Delict 124: "The interests of society are sometimes better served by allowing the injured party to recover damages beyond the compensatory measure than by allowing the wrongdoer to benefit by the fact that some other person has discharged his liability".

Zysset v Santam Ltd 19961 SA 273 (C) 280.

Standard General Insurance Co Ltd v Dugmore 19971 SA 33 (A) 43-45.

Zysset v Santam Ltd 19961 SA 273 (C) 278; Visser and Potgieter Law of Damages 208; Van der Walt 1980 THRHR 26. See also the discussion in para 2.2 above.

Visser and Potgieter Law of Damages 208.
} 
collateral benefits, they do not represent some magic solution to all problems. Furthermore, primitive notions of revenge may actually inspire a decision apparently based on equity. It is also possible that there may be two equally equitable solutions of which the one is, for various reasons, more desirable than the other. ${ }^{24}$

$\mathrm{Koch}^{25}$ argues that in general a wrongdoer must take his victim as he finds him. For instance, if he injures a person with the proverbial "eggshell skull", the damages will unfortunately be substantial. However, if justice were even-handed, injury of a wellinsured victim would likewise require the payment of minimal damages. Koch would therefore argue that benefits received should be taken into account.

Bloembergen ${ }^{26}$ states that it would be unreasonable to isolate the advantageous consequences of the wrongdoer's conduct from its detrimental effects and conclude that the former do not concern the defendant. Anyone who wants to present a defendant with an account of his conduct should (in principle) present a complete account and not omit certain items. Bloembergen would thus also argue that benefits received should be taken into account.

In Santam Versekeringsmaatskappy $v$ Byleveld $t^{27}$ one finds a classic illustration from case law of the application on the basis of fairness of the collateral-source rule. The plaintiff, a mechanic, suffered brain damage in a motor accident which left him permanently unfit for work. Notwithstanding this, his former employer allowed him to perform simple tasks and continued to pay him his salary as a motor mechanic. The court regarded the continuous payment of his salary as an ex gratia payment and on the basis of equity it was disregarded in the calculation of damages.

Another example from case law where the principles of fairness and justice were applied is to be found in Zysset $v$ Santam $L t d .^{28}$ The four plaintiffs, all Swiss citizens domiciled and resident there, were injured in a motor-vehicle collision in Namibia.

\footnotetext{
Visser and Potgieter Law of Damages 239 fn 243.

Koch Reduced Utility 190.

Bloembergen Schadevergoeding 317.

Santam Versekeringsmaatskappy v Byleveldt 19732 SA 146 (A) 151.

Zysset v Santam Ltd 19961 SA 273 (C) 279.
} 
They received financial benefits from two legislatively constituted compulsory socialinsurance schemes in Switzerland, whose object was the protection of the entire population of Switzerland against certain consequences of disease and accident. The plaintiffs entered into an agreement with the Swiss insurance schemes that, in the event of their receiving the full amount of their damages claim, they would repay to the schemes the compensation received from those schemes. In assessing the claim for damages against a local insurance company the question had to be answered whether or not the financial benefits received from the two Swiss socialinsurance schemes should be deducted from the claim for damages.

The court held that no justification could exist for allowing the plaintiffs to be doubly compensated by awarding them compensation under both schemes, since the source of funds for both the motor insurance scheme in South Africa and the Swiss insurance schemes was largely the general public. Nor could it be argued that it would be inequitable or unfair for the motor insurer to be relieved of liability to the extent of the benefits received by the plaintiffs under the other schemes. The court therefore held that the benefits received from the Swiss insurance schemes must be deducted from the plaintiff's claim for damages, but only if the failure to do so would result in double compensation. ${ }^{29}$ Because the plaintiffs entered into an agreement with the Swiss insurance schemes to repay the amounts received if full compensation were awarded to them, the court held that the full compensation must be paid over. If there was a portion of the amount received from the Swiss insurance schemes that was not repayable, that amount should be deducted from their damages. ${ }^{30}$

A number of observations can be made arising from this decision. Firstly, the court correctly stated the equitable principles regarding the avoidance of paying double compensation, especially in instances where the compensation has in essence been funded by the general public. Interesting enough, the court held that it is irrelevant that the funding came from the general public from two different countries. Secondly, the court applied the fairness consideration in respect of relief of liability on the part 
of the defendant. The application of the consideration of fairness and equity thus applies not only to the plaintiff but also to the defendant. A third observation is that the court applied the principle of subrogation to avoid double compensation on the part of the plaintiff, and in spite of its statement about fairness towards the defendant nevertheless held that the defendant must pay the full compensation. Unfortunately the end result was that the local general public partly funded an overseas social scheme.

It is evident from this discussion that it is not always predictable how the courts will apply the principles of fairness, justice and equity, but at the very least these considerations should apply to both the plaintiff and the defendant and, for that matter, also to the public at large, especially in cases of social-security claims.

In Zysset the benefits received originated from a public insurance scheme, whereas the benefits in the two cases under discussion were social grants. This necessitates the need to distinguish between social insurance benefits and social assistance benefits or social grants.

\subsection{Social security, social assistance (social grants) and social insurance}

For the purposes of this article it is important to understand that the Constitution guarantees the right to have access to social security. ${ }^{31}$ Furthermore, social security refers to the protection which society provides for its members through a number of public measures against economic and social distress to those members of society who have no or insufficient income as a result of the occurrence of one or more social contingencies. ${ }^{32}$ These social contingencies include inter alia a condition that requires medical care, sickness, unemployment, old age or the death of a

\footnotetext{
31 Section 27(1)(c) Constitution of the Republic of South Africa, 1996 states that everyone has the right to have access to social security, "including, if they are unable to support themselves and their dependants, appropriate social assistance". See also Olivier, Smit and Kalula Social Security 52, 56 and 58.

32 ILO Social Security 3.
} 
breadwinner. ${ }^{33}$ The latter constitutes a social risk and can also be marked as a damage-causing event where such a death is caused in a wrongful and culpable way.

Where social security is the overarching term, social assistance refers to schemes in terms of the Social Assistance $\mathrm{Act}^{34}$ and its regulations. Recipients of grants in terms of this Act receive assistance from public funds without themselves ever having contributed directly to the scheme. ${ }^{35}$ The $S A A$ also provides for social relief for distress, ${ }^{36}$ which differs from means-tested social assistance in that it entails shortterm measures undertaken by the state in order to assist those undergoing individual or community crises. Means-tested social assistance, on the other hand, provides for the payment of grants to those who qualify for social grants after SASSA had evaluated the income and assets of the person applying for assistance and had established that the person's means are below the stipulated minimum. ${ }^{37}$ In the case of a foster-care grant, the means test entails a consideration of the annual income of the foster child. ${ }^{38}$ This should not exceed twice the maximum pension (grants) paid per annum. Presently, the $S A A$ provides for the payment of a child-support grant, ${ }^{39} \mathrm{a}$ care-dependency grant, ${ }^{40}$ a foster-child grant, ${ }^{41}$ a disability grant, ${ }^{42}$ an older-person's grant, ${ }^{43}$ a war-veteran's grant ${ }^{44}$ and a grant-in-aid. ${ }^{45}$

According to Strydom Social Security 5, the social contingencies or risks are derived from the ILO's Social Security (Minimum Standards) Convention 102 of 1952. See also Olivier, Smit and Kalula Social Security 24. Social Assistance Act 13 of 2004.

35 Olivier, Smit and Kalula Social Security 200 explains that "[s]ocial assistance is generally financed from the general revenue of a country rather than from individual contributions". See also Strydom Social Security 7: "Social assistance is financed through taxes and afforded by a government to those inhabitants who have met with a contingency recognised by law". Section 13 Social Assistance Act 13 of 2004. See Strydom Social Security 12-13 for a discussion of social relief.

37 Strydom Social Security 8.

38 Olivier, Smit and Kalula Social Security 203.

39 Section 6 Social Assistance Act 13 of 2004.

40 Section 7 Social Assistance Act 13 of 2004.

41 Section 8 Social Assistance Act 13 of 2004.

42 Section 9 Social Assistance Act 13 of 2004.

43 Section 10 Social Assistance Act 13 of 2004.

44 Section 11 Social Assistance Act 13 of 2004.

45 Section 12 Social Assistance Act 13 of 2004. 
Social insurance refers to contributory schemes in terms of which benefits for a variety of possible contingencies are paid to a beneficiary because of membership of the scheme and the payment of contributions. ${ }^{46}$ Although the deductibility of socialinsurance benefits from claims for compensation is a very contentious issue in our law and should be researched and commented on, we will refrain from doing so in this article and focus only on instances where social grants in terms of the SAA are relevant, as in the facts of the two conflicting decisions under discussion.

With this theoretical background of the applicable principles of private law and socialsecurity law in mind, the next paragraph takes a look at the two conflicting decisions in Makhuvela $v$ Road Accident Fund ${ }^{47}$ and Road Accident Fund $v$ Timis. ${ }^{48}$

\section{Recent cases on the deductibility of social grants}

\subsection{Introduction}

Ideally, courts should treat like cases alike. This is a fundamental principle of South African law in which precedents are binding and form an important source of the law. ${ }^{49}$ In the two cases under discussion, the two courts should have come to the same conclusion because the facts are essentially the same. The discussion below shows how the opposite in fact transpired.

\subsection{Makhuvela v Road Accident Fund}

In casu, the plaintiff was the grandfather and legal guardian of his grandson. The claim was one for delictual damages arising from the death of the child's father in a

46 Strydom Social Security 10-12 explains that "social insurance is usually compulsory and regulated by the state through legislation. In addition, social insurance is not available to all members of society but is usually restricted to employees (and their dependants in certain circumstances)".

$47 \quad$ Makhuvela v Road Accident Fund 20101 SA 29 (SGHC). See also Van Niekerk 2009 JILB 146.

48 Road Accident Fund v Timis 29/09 2010 ZASCA 30 (26 March 2010). See also Millard "Law of Third Party Compensation".

49 Du Plessis Introduction to Law 239-246.

$50 \quad$ Makhuvela $v$ Road Accident Fund 20101 SA 29 (SGHC). See also Van Niekerk 2009 JILB 146. 
motor-vehicle accident. ${ }^{51}$ The grandparents had been appointed as foster parents and the grandmother was the recipient of a foster-care grant in terms of the $S A A .^{52}$ The only question before the court was whether the foster-care grant that was received by the grandmother should be taken into account or not when calculating damages. $^{53}$

In adjudicating the matter the court referred to Zysset and Others $v$ Santam Ltd, ${ }^{54}$ where it was ruled that insurance payments are regarded as res inter alios acta as it would be wrong for a wrongdoer to benefit from the plaintiff's prudence in providing for himself. ${ }^{55}$ In Zysset the court specifically stated that a decision to regard benefits as res inter alios acta should be based on "considerations of public policy, reasonableness and justice" and a weighing up of the competing interests. ${ }^{56}$ In Makhuvela $^{57}$ the court remarked that the aim of the $S A A$ is to secure the support of foster children but also to realise the constitutional rights of children under section 28 of the Constitution. ${ }^{58}$ The court also considered the fact that a foster parent is eligible for a foster-care grant where a child under 18 years old had been placed in its care. ${ }^{59}$ According to Van Niekerk ${ }^{60}$ these grants are made "subject to various criteria, but regardless of the foster parent's income: only the means of the foster child are considered, they are made to the foster parent, not to the child himself or herself; and they are funded by public moneys". These factors, together with the consideration that "the child never has and will never have a claim to [the grant]", 61 prompted the court to conclude that the foster-parent grant is res inter alios acta and therefore not to be taken into account in calculating the damages payable to the child's guardian by the Road Accident Fund. ${ }^{62}$

Makhuvela v Road Accident Fund 20101 SA 29 (SGHC) 29I-J; Van Niekerk 2009 JILB 146.

Social Assistance Act 13 of 2004.

Makhuvela v Road Accident Fund 20101 SA 29 (SGHC) 30A-C; Van Niekerk 2009 JILB 147.

Zysset $v$ Santam Ltd 19961 SA 273 (C) 277H-279C.

Makhuvela v Road Accident Fund 20101 SA 29 (SGHC) 30G-31B; Van Niekerk 2009 JILB 147.

For a detailed discussion on Zysset, see para 2.3 above.

Makhuvela $v$ Road Accident Fund 20101 SA 29 (SGHC) 32A.

Constitution of the Republic of South Africa Act 108 of 1996; Van Niekerk 2009 JILB 147.

Makhuvela $v$ Road Accident Fund 20101 SA 29 (SGHC) 33G. On the requirements that must be met for a foster-care grant, see para 2.4 above.

Van Niekerk 2009 JILB 147.

Van Niekerk 2009 JILB 147.

Makhuvela v Road Accident Fund 20101 SA 29 (SGHC) 34B-E. 
This particular case illustrates the point made before, namely that in the absence of statutory provisions the courts are left to rule on the deductibility of certain benefits. South African law does not offer a satisfactory answer to this question. ${ }^{63}$

\subsection{Road Accident Fund v Timis $^{64}$}

Although the facts in Makhuvela and Timis were essentially the same, the Supreme Court of Appeal came to a different conclusion in Road Accident Fund $v$ Timis. Ntombizanele Timis was left widowed following the wrongful and negligent killing of her husband, Alfred Makeleni, in a motor-vehicle accident on 28 July 2001. Their two minor children, Siphokaxi and Zandile, were born on 24 June 1996 and 25 May 1999 respectively. The unemployed respondent applied for child-support grants in respect of her two minor children in terms of the $S A A$ and this application was approved. She started receiving these two grants soon after the approval thereof on 1 November 2001.65

The respondent instituted action in the High Court, Port Elizabeth, against the Road Accident Fund for loss of support resulting from her husband's death. The merits of the case were settled but the quantum was in dispute. ${ }^{66}$ So far, it is evident that the damage-causing event in both cases under discussion was the killing of a breadwinner and the loss caused was loss of support. Furthermore, as in the Makhuvela case, the legal question that had to be decided in this case was if the total amount of all the child-support grant payments received by the respondent subsequent to the death of her husband should be deducted from the total amount of compensation payable by the Road Accident Fund. ${ }^{67}$ The same question arose in Makhuvela in respect of a foster-care grant.

\footnotetext{
Neethling and Potgieter Delict 231; Van Niekerk 2009 JILB 147. Road Accident Fund v Timis 29/09 2010 ZASCA 30 (26 March 2010). Road Accident Fund $v$ Timis 29/09 2010 ZASCA 30 (26 March 2010) para 1. Road Accident Fund v Timis 29/09 2010 ZASCA 30 (26 March 2010) para 2. Road Accident Fund $v$ Timis 29/09 2010 ZASCA 30 (26 March 2010) para 2. 
Interestingly, the court a quo discussed the decision in Indrani and Another $v$ African Guarantee and Indemnity Co $\mathrm{Ltd}^{68}$ and Liebenberg $\mathrm{J}$ elected to differ (for no apparent reason) from the court in Indrani. Liebenberg $\mathrm{J}$ ruled that the child-support grants received could not be deducted from the compensation tendered by the Road Accident Fund, ${ }^{69}$ because unlike the Indrani case where the mother received allowances by reason of the death of the father, the child-support grants in casu could not be said to have been received "in consequence" of the deceased's death. ${ }^{70}$ This is clearly strange, as both the allowances in Indrani and the grants in Timis would not have been paid had the father not been killed.

On appeal, the court approached the matter systematically. It stated:

\begin{abstract}
Each case in which the deduction of a benefit is in issue must, of course, be considered on its own facts and having regard to the applicable statutes. It is necessary to have regard to the purpose and objects of the Act. The purpose of the grant is to supplement the income of indigent families. The grants are meant for those who have insufficient means to support themselves and to provide for a child who does not have maintenance. ${ }^{71}$
\end{abstract}

As far as the qualifying criteria are concerned, the court explained that a childsupport grant is payable in terms of section 6 of the $S A A$ and that an applicant qualifies for a grant if certain requirements are met. For instance, applicants must show that they have no income or that their income is below the statutory

Indrani v African Guarantee and Indemnity Co Ltd 19682 SA 606 (D). In casu a mother brought an action for loss of support suffered by her and her minor children as a result of the death of her husband due to a motor-vehicle accident. After the death of the husband, the mother received allowances in respect of maintenance for her and the deceased's children from the state in terms of $s$ 89(1) of the Children's Act 33 of 1960. Fannin J ruled that any contributions by the state prior to the award of damages should be deducted from such award. He further stated that the reason for this is that a dependant entitled to damages for loss of support should be awarded damages only for the material loss caused by the breadwinner's death. The judge held that the allowances were deductible because they were benefits received by the children by reason of the death of their father. 
threshold. $^{72}$ The Supreme Court of Appeal also referred to Santam Versekeringsmaatskappy $v$ Byleveldt ${ }^{73}$ where the court followed a similar approach.

Finally, the court ruled that where a surviving spouse institutes a claim for loss of support for her child as a result of the death of the child's father, child-support grants which have been received by her are directly linked to the death of the deceased and are deductible from the final award. It follows that there are no merits in the argument that the payment of the child-support grants were not causally linked to the death of the deceased breadwinner. Mhlantla JA states:

It is not in dispute that the deceased was responsible for the support of his family during his lifetime. The position, however, changed upon his death as his family became indigent. The respondent had to apply for the child care grant as the parent who had provided maintenance had died. The children received a benefit of a social grant because they had lost their father, a breadwinner.... The child support grants are therefore directly linked to the death of the deceased. ${ }^{74}$

\subsection{Analysis of Makhuvela and Timis}

It is respectfully submitted that the court came to the wrong decision in Makhuvela for two reasons. Firstly, there is a direct link between the child's father's death and his being placed in foster care with his grandparents. Secondly, his grandmother would not have applied for and received the foster-care grant had he not been placed in foster care. Put differently, before the father's death the father earned enough to support his child and there was absolutely no need for assistance from the welfare. Upon the father's death, the child's only source of income fell away, leaving him indigent. This prompted his foster parent to apply for a foster-care grant. These events are directly linked and the court made a mistake in ignoring this.

72 Road Accident Fund v Timis 29/09 2010 ZASCA 30 (26 March 2010) para 6. This pertains to the "means test". See par a2.4 above for a discussion of the means test.

73 Santam Versekeringsmaatskappy v Byleveldt 19732 SA 146 (A) 173-174. Also refer to para 2.3 above, where this case is viewed from a private-law perspective.

74 Road Accident Fund v Timis 29/09 2010 ZASCA 30 (26 March 2010) para 10. The court also referred to the English case of Hodgson $v$ Trapp 19883 All ER 870 (HL) where that court came to a similar decision. 
Therefore, to establish a direct link is the first step. Where there is no such link, it is likely that the issue of collateral benefits would not arise. Where there is such a link, the second step is to determine how the grant and the subsequent settlement paid by a wrongful, culpable wrongdoer (or the Road Accident Fund) affect the circumstances of a particular individual. In Makhuvela the court needed only to look at the means test. If a settlement paid by a wrongdoer (or the Road Accident Fund) meant that the child's annual income would become too high, it follows that the foster parent no longer qualifies for a foster-care grant. Instead, the settlement amount which reflects the child's loss in the ordinary sense of the word now suffices for the child's support and he is no longer considered indigent. In Makhuvela the court did indeed acknowledge that it is the means of the child which is considered, but the court failed to lead that argument to a logical conclusion: Where a child has sufficient income because of an inheritance or a trust fund or subsequent damages being paid by a wrongdoer (or the Road Accident Fund), there is no financial burden on the foster parent. He can take care of the child from the inheritance, trust fund or damages payment and will therefore not qualify for a foster-care grant.

For any social grant the means test is therefore pivotal in the second step of the process. In the case of a foster-care grant, the means test entails a consideration of the annual income of the foster child. ${ }^{75}$ This should not exceed twice the maximum pension (grants) paid per annum. Therefore, if the foster-care grant for argument's sake amounted to R680 per month for that given year, the child's income should not have been more than R680 $\times 12 \times 2$ which is R16 320. If it were accepted that the child's loss of income was less than R16 320 per year, the grandmother would be eligible for the grant. However, had it been more than R16 320, the grandmother would not have qualified for the foster-care grant in the first place and there would not have been an argument on trial about res inter alios acta. ${ }^{76}$

In Makhuvela the court failed to recognise the link between the father's death and the grandmother's receiving the grant, and the remainder of the judgment is of little use when dealing with child support or other grants because the means test and other

75 Olivier, Smit and Kalula Social Security 203. 
requirements differ. However, the suggested two-phase approach can be employed in other cases where there is a dispute on the deductibility of social grants from damages paid by wrongdoers (or the Road Accident Fund). When applying this twophase approach to the Timis case, the first step would be to establish if the payment of the child-support grant to the mother was a direct consequence of the father's wrongful, culpable death. The court correctly concluded that the mother would not have received the grant had it not been for the death of her husband, who was the sole breadwinner. The first step being dealt with, the court then moved to the second enquiry, namely whether the child-support grants already received should be taken into account. The court answered this question in the affirmative, which effectively meant that the damages allowed for past loss should be reduced with the total amount of all the grants paid to date of trial. One could argue that the court decided to deduct the grants received simply because there was a direct link between the receipt of the grant and the death of the father, and that no further enquiry was made or the circumstances investigated.

It is with this second step in Timis that one can in fact take issue, because the court did not consider the individual circumstances of the recipient of the grants. Let's argue that the breadwinner in Timis was employed but still factually indigent while he was alive, and could in fact have qualified for a child-support grant while he was alive. He supported his family, however, on his very small income and never considered applying for a social grant. His subsequent death and the loss of his meager earnings prompted his widow to apply for the grant. She qualified but the grant was still less than her needs. Such a scenario would change the picture completely and the key to doing justice in this case lies once again in doing the arithmetic and applying the means test. If the widow is entitled to very little by means of compensation and that still leaves her indigent for the purposes of the means test she would continue to qualify for the child-support grant. There cannot be a blanket rule demanding the deduction of the grants already received, as was applied in Timis. Step two, as applied in the case of Timis, had acceptable results because the father was gainfully employed before his death. But that blanket rule to always deduct the grant, if exported to cases such as the hypothetical one described above, would have unfair results. 
One has to admit in all fairness that an application of the correct legal position as stated in the above paragraph involves an ex post facto evaluation of the chronological events following the child's father's death, and these facts were not placed in front of the court in Timis. What this entails is a time-line indicating the date of the breadwinner's death and the date upon which the child was placed in the care of his foster parents or became the sole responsibility of the surviving, indigent spouse. The reality of cases such as this one is that the foster parents or indigent parent becomes responsible for taking care of a child immediately after the death of the child's parent and monies owed to the child by pension funds, insurances and institutions such as the Road Accident Fund pay out sometime in the future only. Therefore, the grandmother in Makhuvela and the mother in Timis qualified to receive the grants at the time when they applied for them because they met the criteria, including the means test.

One can see that it is not simply a matter of voting "yes" or "no" when deciding whether a welfare grant is res inter alios acta or not. If the Timis case led to fair results it was probably because the court would have come to the same conclusion even if the two-phase approach, as suggested above, had been properly followed. In the quest to be fair to both parties to the dispute and to be accountable to the taxpaying public, this complicated issue should also be viewed from a constitutional perspective.

\section{$4 \quad$ Legislative provisions and the Constitution}

Where statutory provisions apply to the quantification of damages, those provisions are prescriptive, which means that they must be adhered to. Furthermore, all statutory provisions should be interpreted against the values of the Constitution. To that end, section 39(2) of the Constitution states that "when interpreting any legislation, and when developing the common law or customary law, every court, tribunal or forum must promote the spirit, purport, and objects of the Bill of Rights". Typical constitutional rights that are relevant to social-security claims are inter alia 
the right to equality and non-discrimination (s 9), ${ }^{77}$ the right to health care, food, water and social security (s 27), ${ }^{78}$ and children's rights (s 28). ${ }^{79}$ Where conflict exists between two provisions from different statutes, the legislation should be interpreted and the common law developed to promote the spirit, purport and objects of the Bill of Rights and any law (legislation or common law) which is inconsistent with the Constitution is invalid.

In claims for damages one often finds that more than one statute may be applicable. For instance, one single claim may be subject to the Assessment of Damages Act, ${ }^{80}$ the Apportionment of Damages Act, ${ }^{81}$ the Road Accident Fund $A c t,{ }^{82}$ the COIDA and even the $S A A$ in addition to common-law rules. Here, private law and social-security law interact. Features common to both include first and foremost that the same damage-causing event, such as an accident which causes injuries or death, literally sets into motion a dedicated system in terms of which benefits, compensation or both are payable to the victim or his or her dependants. Furthermore, a victim may theoretically be entitled to a variety of benefits and compensation from different sources but it is essentially a policy issue whether or not to award all those amounts to the victim. A worker who drives a delivery vehicle and is injured in a car accident between two deliveries will for instance be entitled to claim from the Road Accident Fund and from the Director-General: Labour. ${ }^{83}$ Also, in both social-security law and private law a victim needs to prove his entitlement to compensation or benefits ${ }^{84}$ and

77 Olivier, Smit and Kalula Social Security 134 (persons excluded from the "employee" concept). On discrimination and social security in general, see Strydom Social Security 224-236.

Olivier, Smit and Kalula Social Security 54-59.

Olivier, Smit and Kalula Social Security 380-381.

Assessment of Damages Act 9 of 1969.

Apportionment of Damages Act 34 of 1956.

Road Accident Fund Act 56 of 1996 (as amended by Act 19 of 2005).

See Road Accident Fund $v$ Monjane 20103 SA 641 (SCA) as an example of one such instance. A victim who institutes a delictual claim needs to prove the elements of a delict, namely that there was a wrongful and culpable act that had caused damage. See in general Neethling and Potgieter Delict 4. In social security, it is necessary for a potential beneficiary to prove his entitlement with reference to a particular statute such as the COIDA. Here, it is necessary to prove first and foremost that the victim was an employee and that the accident took place in the scope of his or her employment. See in general Olivier, Smit and Kalula Social Security 459-460. 
where there is such an entitlement, there may be limitations on the extent of what the victim is entitled to. ${ }^{85}$

Having said this and returning once again to collateral benefits and social grants, it is glaringly obvious that there were no concerted efforts by the courts, in any event not before the case of Timis, to integrate social-security law and private law. A possible explanation for this is that law of delict and social-security law have completely different objectives. As was stated above, it is the aim of delictual compensation to fully indemnify a victim of injury or death for all losses suffered due to the damagecausing event. ${ }^{86}$ In contrast, social security law, albeit social insurance or social assistance (grants), aims at providing statutorily defined benefits, which benefits are either funded solely by taxes (such as social grants and compensation paid by the Road Accident Fund) or contributions (such as COIDA or UIF benefits).

Awareness of this muddle between private law and social-security law seems to have prompted the legislator to move more towards defined benefits and further away from delictual compensation, specifically in the area of road accidents. Interestingly, the Department of Transport's Draft Policy on the Restructuring of the Road Accident Fund as a Compulsory Social Insurance in Relation to the Comprehensive Social Security System ${ }^{87}$ states that as far as collateral benefits are concerned "[b]enefits paid to the claimants for the same injury or death from private and employment sources will not be deductible from the RABS benefits payable". To avoid double dipping, benefits paid from other state or public sources (such as social grants) will be deducted by the $R A B S A .{ }^{88}$ It is submitted that this is a step in the right direction, at least in that it may ensure that tax-funded compensation funds communicate with one another and attempt to preserve resources and to be accountable to both the taxpaying public and the recipient. This should be the

85 A delictual claim may for instance be limited by the Apportionment of Damages Act 34 of 1956 or due to the application of principle of mitigation of loss. There are often thresholds in social security, and benefits are capped. See in general s 35(1) Compensation for Occupational Injuries and Diseases Act 130 of 1993 and s 21 Road Accident Fund Act 56 of 1996 (as amended by Act 19 of 2005).

See para 2.3 above.

Gen N 121 in GG 32940 of 12 February 2010 (hereafter "Restructuring of the RAF").

Restructuring of the RAF 62. 
objective where compensation or benefits are paid from tax funds. Where a victim was indigent before and after a damage-causing event and qualified for social grants throughout, the effect of the RABS will simply be to transplant a recipient from one system (such as the social-grant system) to another (such as the RABS).

\section{$5 \quad$ Conclusion and recommendations}

Whenever the legislature leaves a vacuum or enacts ambiguous and conflicting statutory provisions, the courts will attempt to clarify the position. Unfortunately this often leads to even more confusion and uncertainty. There is definitely a need for proper guidelines to assist the courts in adjudicating on issues such as those that arose in Makhuvela and Timis, not only because it is desirable to be accountable to the taxpaying public, but also because of the constitutional imperative to provide everyone with access to social security and the common-law duty to compensate the victims of a wrongful, culpable, damage-causing event. Herein lies the difficulty.

Whereas it is the objective of social security to ensure that social risks such as the permanent disability or death of the breadwinner are managed in such a way as to prevent destitution, it is the objective of the law of damages to provide "just, logical and practical rules and principles in solving problems regarding the determination of damage, damages and satisfaction". ${ }^{89}$

It is submitted that double dipping cannot be equated with collateral benefits for a variety of reasons. The first and foremost reason is that the objectives of socialsecurity law and the law of damages differ. Also, double dipping is used only in the context of social security, whereas collateral benefits go much wider and speak to a variety of matters not limited to social-security law. Finally, social-security law and private law have developed in isolation and one should be careful not to throw these

89 Visser and Potgieter Law of Damages 4. Importantly, not all collateral benefits stem from sources that may be grouped together under the umbrella of social security. For instance, privateinsurance benefits and ex gratia payments have never been taken into account when calculating a plaintiff's common-law damages (Neethling and Potgieter Delict 228). However, payments received from the Compensation Commissioner or Director-General: Labour have been deducted from the plaintiff's settlement amount (Neethling and Potgieter Delict 230 and in particular Ngcobo v Santam Insurance Co Ltd 19942 SA 478 (T)). 
concepts into the same basket. At the same time, it has become important to be increasingly mindful of the interaction between social-security law and private law.

This article therefore makes a number of recommendations. In the absence of clear statutory provisions and until such time that these have been enacted, it is suggested that in the event of a victim claiming loss of support because of the wrongful, culpable death of a breadwinner where such victim is the beneficiary of a child-support grant or a foster-care grant, the first step is to establish if the grant was paid as a direct result of the breadwinner's death. If this is in fact the case, the second step is to determine how the grant and the subsequent settlement paid by a wrongful, culpable wrongdoer (or the Road Accident Fund) will affect the circumstances of a particular individual or family. This involves the application of the means test employed for the particular grant. If a family would have qualified for the grant before the damage-causing event it would be unfair to regard the grant payment as res inter alios acta because it effectively denies access to social security.

This suggested two-phase approach is complicated. Therefore it is imperative to recognise the complexity of the issues raised here and to look for appropriate statutory interventions. As explained above, existing statutory provisions pertaining to issues such as "double dipping" and res inter alios acta are either unclear, conflicting or inconsistent, and an in-depth review of the $S A A$ and other socialsecurity legislation should aim to achieve consistent, fair treatment.

Thorough legislative review will almost certainly reveal that social-security law and private-law measures do not belong to different realms but form part of the South African legal system in that both are subject to the Constitution. This fact was highlighted by Makhuvela and Timis, regardless of whether one agrees with the two judgments or not.

These recommendations are not exhaustive, but further supplementation pertaining to social-security benefits other than social grants falls outside the scope of this discussion. Suffice it to say that no modern legal practitioner in personal-injury law 
can approach these cases without a working knowledge of the interplay of socialsecurity law and private law, as became evident in Makhuvela and Timis. Hopefully the legislator will recognise the urgent need for appropriate statutory reform in this area of our law. 


\section{Bibliography}

Bloembergen Schadevergoeding

Bloembergen AR Schadevergoeding bij Onrechtmatige Daad (Kluwer Deventer 1965)

Boberg Law of Delict

Boberg PQR The Law of Delict: Vol 1 Aquilian Liability (Juta Cape Town 1984)

Du Plessis Introduction to Law

Du Plessis L An Introduction to Law (Juta Cape Town 1999)

ILO Social Security

International Labour Organisation Introduction to Social Security (ILO Geneva 1989)

Koch Reduced Utility

Koch RJ The Reduced Utility of a Life Plan (LLD thesis US Stellenbosch 1993)

McKerron Delict

McKerron RG The Law of Delict $7^{\text {th }}$ ed (Juta Cape Town 1971)

Millard "Law of Third Party Compensation"

Millard D "Law of Third Party Compensation and Insurance Law" (Unpublished paper read at the University of Johannesburg's Annual Banking Law Update 21 April 2010 Johannesburg) 
Neethling and Potgieter Delict

Neethling $\mathrm{J}$ and Potgieter JM Neethling-Potgieter-Visser Law of Delict (LexisNexis Butterworths Durban 2010)

Olivier, Smit and Kalula Social Security

Olivier MP, Smit N and Kalula ER Social Security: A Legal Analysis (LexisNexis Butterworths Durban 2003)

Plamondon Actuarial Practice

Plamondon P et al Actuarial Practice in Social Security (ILO Geneva 2002)

Strydom Social Security

Strydom EML (ed) Essential Social Security Law (Juta Cape Town 2001)

Van der Walt 1980 THRHR

Van der Walt CFC "Die voordeeltoerekeningsreël - 'n knooppunt van uiteenlopende teorieë oor die oogmerk met skadevergoeding" 1980 THRHR $1-26$

Van der Walt and Midgley Delict

Van der Walt JC and Midgley JR Principles of Delict $3^{\text {rd }}$ ed (LexisNexis Butterworths Durban 2004)

Van Niekerk 2009 JILB Van Niekerk JP "Makhuvela v Road Accident Fund" 2009 JILB 146-147

Visser and Potgieter Law of Damages

Visser PJ and Potgieter JM Visser and Potgieter's Law of Damages $2^{\text {nd }}$ ed (Juta Cape Town 2003)

Register of court cases

Hodgson v Trapp 19883 All ER $870(\mathrm{HL})$ 
Indrani v African Guarantee and Indemnity Co Ltd 19682 SA 606 (D)

Makhuvela v Road Accident Fund 20101 SA 29 (SGHC)

Mankayi v Anglo Gold Ashanti Ltd 40/10 2011 ZACC 3 (3 March 2011)

Ngcobo v Santam Insurance Co Ltd 19942 SA 478 (T)

Pharmaceutical Manufacturers Association of $S A$ : in re ex parte President of the Republic of South Africa 20003 BCLR 241 (CC)

Road Accident Fund v Monjane 20103 SA 641 (SCA)

Road Accident Fund v Timis 29/09 2010 ZASCA 30 (26 March 2010)

Santam Versekeringsmaatskappy v Byleveldt 19732 SA 146 (A)

Standard General Insurance Co Ltd v Dugmore 19971 SA 33 (A)

Zysset v Santam Ltd 19961 SA 273 (C)

\section{Register of legislation}

Apportionment of Damages Act 34 of 1956

Assessment of Damages Act 9 of 1969

Children's Act 33 of 1960

Compensation for Occupational Injuries and Diseases Act 130 of 1993

Constitution of the Republic of South Africa, 1996

Road Accident Fund Act 56 of 1996 (as amended by Act 19 of 2005)

Social Assistance Act 13 of 2004

Social Security (Minimum Standards) Convention 102 of 1952 (ILO)

\section{Register of policy documents}

Draft Policy on the Restructuring of the Road Accident Fund as a Compulsory Social Insurance in Relation to the Comprehensive Social Security System (Gen N 121 in GG 32940 of 12 February 2010) 


\section{List of abbreviations}

COIDA Compensation for Occupational Injuries and Diseases Act 130 of 1993

JILB Juta's Insurance Law Bulletin

THRHR Tydskrif vir Hedendaags Romeins-Hollandse Reg

RABS Road Accident Benefit Scheme

RABSA Road Accident Benefit Scheme Administrator

SAA Social Assistance Act 13 of 2004

SASSA South African Social Security Agency

TSAR Tydskrif vir die Suid-Afrikaanse Reg 